\title{
Corn oil enhances progesterone and estradiol plasma levels in tropical hair sheep
}

\section{El aceite de maíz incrementa los niveles séricos de progesterona y estradiol en ovejas de pelo}

\author{
Victor Manuel Meza-Villalvazo ${ }^{1 *}$, Hector Magaña-Sevilla ${ }^{2}$, Crystelli Alicia Rojas-Marquez ${ }^{1}$, Carlos \\ Sandoval-Castro ${ }^{3}$, Alfredo Trejo-Cordova ${ }^{4}$ \\ ${ }^{1}$ Instituto de Biotecnología, Universidad del Papaloapan, Circuito Central 200, Col. Parque Industrial, CP. 68301. Tuxtepec, \\ Oaxaca, México. \\ ${ }^{2}$ Instituto Tecnológico de Conkal. Km 16.3 Antigua Carretera Merida-Motul, Conkal Yucatán México. \\ ${ }^{3}$ Facultad de Medicina Veterinaria y Zootecnia. Universidad Autónoma de Yucatán. Apdo. 4-116 Itzimna, Mérida, Yucatán, \\ México. \\ ${ }^{4}$ Departamento de Biología de la Reproducción, División de Ciencias Biológicas y de la Salud, Universidad Autónoma \\ Metropolitana Unidad Iztapalapa. Av. San Rafael Atlixco, Núm. 186, Col. Vicentina, Delegación Iztapalapa, CP. 09340. \\ Ciudad de México, México. \\ ${ }^{*}$ Corresponding author: meza1077@hotmail.com
}

Scientific note received: June 20, 2017 accepted: March 02, 2018

\begin{abstract}
The objective of the present study was to evaluate the inclusion of corn oil in the diet of sheep and its effect on serum levels of progesterone and estradiol, Twenty-one Pelibuey sheeps were divided into three treatments based on the level of oil included in the diet $(\mathrm{T} 0=0, \mathrm{~T} 3=3$ and $\mathrm{T} 6=6 \%$ respectively, on dry basis). Blood samples were obtained to determine hormones in serum. Cholesterol and progesterone were higher for T3 and T6 treatments ( $p<0.05)$ compared to T0. Insulin was higher $(\mathrm{p}<0.05)$ in the T6 treatment compared to treatments T3 and T0. At the time of ovulation, estradiol concentration was higher $(\mathrm{p}<0.05)$ for treatments T3 and T6 compared to T0. The inclusion of corn oil in the diet increases the levels of cholesterol, progesterone, estradiol and insulin in sheep hair.
\end{abstract}

Key words: cholesterol, ovarian hormones, insulin, blood serum

RESUMEN. El objetivo del presente estudio fue evaluar la inclusión del aceite de maíz en la dieta de ovejas y su efecto en los niveles séricos de progesterona y estradiol, Veintiún ovejas Pelibuey fueron divididas en tres tratamientos con base al nivel de aceite incluido en la dieta $(\mathrm{T} 0=0, \mathrm{~T} 3=3$ y $\mathrm{T} 6=6 \%$ respectivamente, en base seca). Se obtuvieron muestras sanguíneas para determinar hormonas en suero. El colesterol y la progesterona fueron mayores para los tratamientos T3 y T6 $(\mathrm{p}<0.05)$ en comparación con T0. La insulina fue mayor $(\mathrm{p}<0.05)$ en el tratamiento T6 en comparación con los tratamientos T3 y T0. En el momento de la ovulación, la concentración de estradiol fue mayor $(\mathrm{p}<0.05)$ para los tratamientos T3 y T6 en comparación con T0. La inclusión de aceite de maíz en la dieta incrementó los niveles de colesterol, progesterona, estradiol e insulina en ovejas de pelo.

Palabras clave: Colesterol, hormonas ováricas, insulina, suero sanguíneo

\section{INTRODUCTION}

Reproduction in ruminants is influenced by several factors such as species, breed, physiological state, nutrition, and others. Within these factors, nutrition is both a requirement and a management tool, while dietary fat is an important source of fatty acids and energy accordingly. However, for strategies of lipid supplementation, it is important to consider the percentage of inclusion in the diet. In ruminants, oils rich in linoleic acids at $4 \%$ of the diet on a dry matter basis, do not show deleterious effects on productive performance (Roy et al. 2017). The mechanisms by which oil improves 
animal reproductive capacity were established as energetic and efficiency, by avoiding de novo synthesis of several compounds. However, an improvement in energy status may be mediated by changes in metabolic hormones (Scaramuzzi et al. 2006). Lipid levels consumed in the diet are associated with a modification in lipid metabolites in plasma, the increase in ovarian steroid secretion and other enzymes involved indirectly in reproductive processes of ruminants (Gulliver et al. 2012). Salas et al. (2011) mention that higher dietary lipids are directly related to an increased concentration of serum cholesterol and high-density lipoproteins in follicular fluid. Cholesterol is a precursor to estradiol synthesis and progesterone and therefore may alter their blood serum concentration, affecting positively or negatively reproductive aspects (Rahbar et al. 2014). Insulin could be considered another important metabolic hormone in the reproduction of the ewe; insulin is key on signaling the metabolic status of the animal, and in this context, can alter the frequency and concentration of $\mathrm{LH}$ and thus the ovarian response when interacting with glucose and leptin (Vinoles et al. 2005, Velazquez et al. 2008). In ruminants, insulin exerts a direct action on the membrane of granulosa cells, an action that may be required for the development of an optimal steroidogenic status (Dupont et al. 2014), that brings a better development of corpus luteum cells, a reduction in the synthesis of PGF2 $\alpha$ (Mattos et al. 2000) and hence a delay in luteolysis (Williams 1989). The objective of the present investigation was to evaluate the inclusion of corn oil in the diet of sheep and its effect on cholesterol, insulin, estradiol, and progesterone blood serum profiles.

\section{MATERIALS AND METHODS}

This experiment was performed according to the procedures established by bioethics committee of the Universidad del Papaloapan (CBUNPA/201603). The study was carried out during the spring season at the experimental area campus Loma Bonita, Oaxaca, located in the geographical coordinates $95^{\circ} 53^{\prime}$ North Latitude and $18^{\circ} 06^{\prime}$ west longitude, at a height of 30 meters above sea level. Twenty-one adult multiparous, non-lactating Pelibuey ewes were used, with a body condition (BC) at the start of the experiment of $2.7 \pm 0.2$ points on a scale of 1-5 (Russel et al. 1969) and body weight of $33.9 \pm 1.57 \mathrm{~kg}$. The sheep were confined for a period of 28 days, and randomly distributed into three treatments, isoenergetic (8.9 MJ $\left.\mathrm{d}^{-1}\right)$ and isoproteic $(10.5 \% \mathrm{CP})$, differing on corn oil level used: T0: $(0 \%, \mathrm{n}=7)$, T3: $(3 \%, \mathrm{n}=7)$, and T6: $(6 \%, n=7)$. Diets were balanced according to requirements for sheep (ARFC 1993).

The estrus synchronization protocol (PGF2 $\alpha$ : Dinoprost, Lutalyse, Pfizer) and blood sampling times are shown in figure 1 . The blood samples were collected $(10 \mathrm{ml})$ from each ewe by jugular vein puncture using EDTA vacutainer tubes (10\%). The samples were kept under refrigeration for less than $60 \mathrm{~min}$, centrifuged at $1460 \mathrm{~g}$ for $10 \mathrm{~min}$, and plasma was extracted and stored at $-20{ }^{\circ} \mathrm{C}$ until analysis.

Hormone measurement: Insulin was determined by radioimmunoassay (Insulin Cout a Count, DPC, USA). Coefficients of variation for intra and inter assay insulin were 11.1 and $13.5 \%$, respectively. Progesterone (P4) was analyzed by radioimmunoassay using a commercial kit (DPC, TKPGX, LAG, USA.), the intra and inter assay coefficient of variation was 6.54 and $2.92 \%$, respectively, cholesterol: an enzymatic method was used (Sera Pak Plus, Bayer, Germany) and estradiol (E2): was analyzed by radioimmunoassay (DPC, California, USA).

Plasma cholesterol and progesterone were analyzed using a one-way ANOVA; insulin and estradiol were analyzed using a repeated measures two-way ANOVA (mixed model), where treatment and the time interval were the fixed effects. Data analysis were performed using the statistical software GraphPad Prism 5.

\section{RESULTS AND DISCUSSION}

The sheep weight at the beginning and end of the experiment, average daily weight gain (DWG) and $B C$ did not vary on any the level of corn oil in 


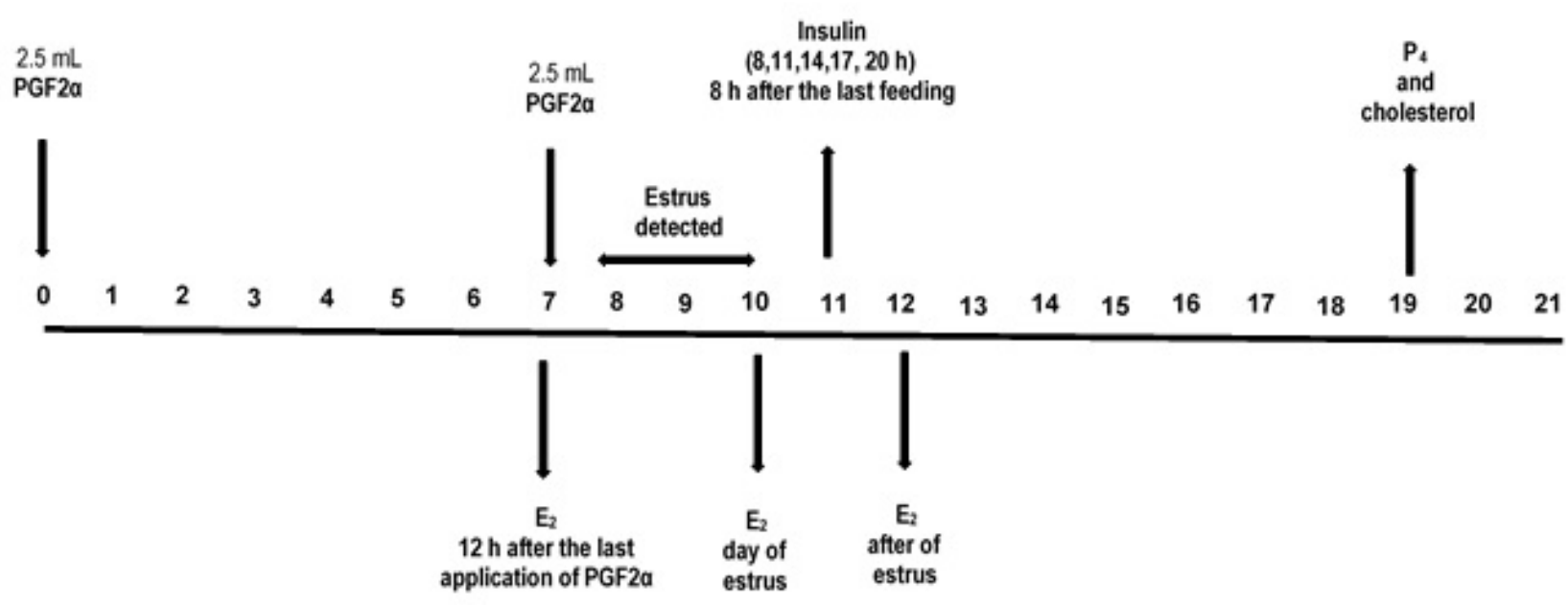

Figure 1. Schematic diagram of estrus synchronization and collection of blood samples.

Table 1. lood serum concentration of Progesterone $\left(\mathrm{ng} \mathrm{ml}^{-1}\right)( \pm \mathrm{SD})$ and Cholesterol $(\mathrm{mg} / \mathrm{dl})( \pm \mathrm{SD})$ at the luteal phase in tropical hair sheep supplemented with corn oil at three levels on a dry matter basis.

\begin{tabular}{cccc}
\hline & \multicolumn{3}{c}{ Treatments } \\
\cline { 2 - 4 } Variable & $0 \%$ & $3 \%$ & $6 \%$ \\
\hline Cholesterol & $102.14 \pm 2.65^{b}$ & $106.42 \pm 3.48^{a}$ & $108.57 \pm 3.40^{a}$ \\
Progesterone & $2.34 \pm 0.66^{b}$ & $3.31 \pm 0.48^{a}$ & $3.88 \pm 0.24^{a}$ \\
\hline SD: Standard deviation, ${ }^{a, b}$ Means with different letters in the same row, \\
indicate significant differences $(\mathrm{p}<0.05)$.
\end{tabular}

the diet, and the daily weight gain did not show differences between treatments either $(p>0.05)$. Since diets were isoenergetic and isoproteic, and calculated for a positive nutrient balance, the ewes expressed positive DWG. However, as the oil in the diet increased, DWG did the opposite (T0: $72.57 \pm$ 0.02, T3: $63.00 \pm 0.01$ and T6: $48.85 \pm 0.02)$. It has been reported that the addition of fat sources in excess of $6 \%$ of the diet on a dry matter basis, causes a depression in dry matter fiber and energy digestibility (Hess et al. 2008), and changes the pattern of fermentation (Fiorentini et al. 2015). Jenkins et al. (2002) fed diets based on corn and soybean oil to grazing sheep, and observed a decrease in the ruminal acetic: propionic ratio. In this sense, feeding fat to the ruminant animal induces a lower energy efficiency and a greater proportion of acetic acid. Otherwise, an increase in the molar ratio of propionic acid generally results in a better
DWG (Al-Arif et al. 2016).

The serum concentration of progesterone and cholesterol was similar between treatments T3 and T6, however, there was a difference $(p<0.05)$ compared with the control group (T0) in the luteal phase of the estrous cycle (Table 1). At higher oil levels in the diet, the level of cholesterol and progesterone concentrations rised. These responses corn oil supplementation, increases the energy concentration of rations and thus promotes the production of steroid hormones (Santos et al. 2008). There is evidence that indicates that after supplementation with lipids, blood serum and follicular cholesterol (Staples et al. 1998) and progesterone increase (Moriel et al. 2014), resulting in a longer middle life of the corpus luteum (Fontona and Torre 2016). Ghoreishi et al. (2007) reported that an increase of plasma progesterone in sheep supplemented with fatty acids is especially important when 
Table 2. Insulin concentration in serum (mean \pm standard deviation, $\mathrm{ng} \mathrm{ml}^{-1}$ ), after estrus in tropical hair sheep supplemented with three levels of corn oil as percent of the diet on a dry matter basis.

\begin{tabular}{cccc}
\hline & \multicolumn{3}{c}{ Treatments } \\
\cline { 2 - 4 } Time after estrus initiation $(\mathrm{h})$ & $0 \%$ & $3 \%$ & $6 \%$ \\
\hline 8 & $1.77 \pm 0.30^{b}$ & $1.81 \pm 0.22^{b}$ & $2.79 \pm 0.20^{a}$ \\
11 & $1.76 \pm 0.17^{b}$ & $1.91 \pm 0.23^{b}$ & $2.13 \pm 0.18^{a}$ \\
14 & $1.44 \pm 0.57^{b}$ & $1.67 \pm 0.14^{b}$ & $2.24 \pm 0.15^{a}$ \\
17 & $1.49 \pm 0.10^{b}$ & $1.90 \pm 0.13^{b}$ & $2.49 \pm 0.20^{a}$ \\
20 & $1.514 \pm 0.131^{b}$ & $1.943 \pm 0.171^{b}$ & $2.918 \pm 0.134^{a}$ \\
\hline
\end{tabular}

SD: Standard deviation, ${ }^{a, b}$ Means with different letters in the same row, indicates statistical differences $(p<0.05)$.

Table 3. Blood serum concentration of Estradiol ( $\left.p g \mathrm{dl}^{-1}\right)( \pm \mathrm{SD}$ ) before, at and after estrus in tropical hair sheep supplemented with corn oil at three levels on a dry matter basis.

\begin{tabular}{cccc}
\hline Days to estrus & \multicolumn{3}{c}{ Treatments (percent oil in the diet) } \\
\cline { 2 - 4 } presentation & $0 \%$ & $3 \%$ & $6 \%$ \\
\hline-2 & $8.34 \pm 0.82^{b}$ & $9.77 \pm 0.68^{a}$ & $9.27 \pm 0.84^{a}$ \\
0 & $11.41 \pm 1.36^{b}$ & $13.53 \pm 0.92^{a}$ & $13.64 \pm 0.48^{a}$ \\
2 & $10.71 \pm 1.48^{b}$ & $12.81 \pm 0.63^{a}$ & $12.09 \pm 0.63^{a}$ \\
\hline
\end{tabular}

SD: Standard deviation. Means with different superscript letters in the same row, are different $(p<0.05)$.

these concentrations are maintenance in the luteal phase of the estrous cycle, because it generates a positive effect on pregnancy establishment and maintaining, since cholesterol is necessary for the synthesis of progesterone. For that reason, the increased availability of cholesterol generates a positive effect on reproductive behavior. Wehrman et al. (1991) reported that luteal cells from cows fed with $6.6 \%$ lipids in the diet have an increased secretion of pregnenolone and progesterone compared to those who received $2.2 \%$. Another factor to consider is the effect exerted by the fatty acids in the synthesis of prostaglandins, which may serve as precursors or inhibitors of the synthesis of PGF $2 \alpha$ depending on the fatty acid concentration in tissues where they are synthesized (Patterson et al. 2012). In sheep, uterine epithelial cells have shown a reduction up to $50 \%$ of the PGF $2 \alpha$, when they are treated with linoleic and linolenic acid (Zhangrui et al. 2005), and that the polyunsaturated fatty acids may also inhibit the synthesis of PGF2 a and hence induce a delay in luteolysis (Gulliver et al. 2012).

The serum concentration of insulin (Table 2) was affected by the highest oil level $(6 \%)$ included in the diet $(p<0.05)$ compared to the T0 and T3 concentrations. Mean levels of insulin $\left(\mathrm{ng} \mathrm{ml}^{-1}\right)$ in the present study are similar to those reported by Espinoza et al. (2008) when supplementing ewes with bovine fat $(2.5 \pm 0.11)$, a control diet $(1.78$ $\pm 0.11)$ and calcium soaps of fatty acids (1.72 \pm 0.11). Herrera et al. (2003) found no differences between the levels of this hormone in sheep fed with 0 and $3 \%$ corn oil, a similar result of the one present work. Williams and Stanko, (2000) reported a higher insulin concentration in cows supplemented with polyunsaturated fatty acids and found that linoleic acid increases propionate production, which acts as a promoter of insulin secretion and prevents mobilization of adipose tissue fat. High concentrations of insulin reduce hepatic expression of progesterone catabolic enzymes such as cytochromes P450 $2 \mathrm{C}$ and 3A (Lemley et al. 2008) and increases circulating progesterone concentrations (Moriel et al. 2008, Lopes et al. 2009).

Estradiol concentrations (Table 3 ) in plasma were increased in sheep with supplemented corn oil treatments $(p<0.05)$ compared to the animals in the control group, and concentrations of this hormone became higher as ovulation approached. Robinson et al. (2002) reported an increase in blood 
serum estradiol in dairy cows supplemented with 18:3 and 18:2 fatty acids, compared with a control group. Similarly, Zachut et al. (2008) reported a greater estradiol concentration in plasma when cows were fed low and high levels of polyunsaturated fatty acids ( 4.9 and $5.1 \mathrm{pg} \mathrm{ml}^{-1}$ ) compared with the control group $\left(3.5 \mathrm{pg} \mathrm{m}^{-1}\right)$. Concentrations of estradiol in blood plasma were positively related to oestrus length (Mondal et al. 2006), the diameter of the preovulatory follicle, and pregnancy rate in cows (Perry et al. 2014). Plasma levels of estradiol reported in this study could be attributed to an increase in ovarian steroidogenesis or possibly to decrease in steroid catabolism in the liver
(Zachutl et al. 2011). The in vitro addition of C18: $3 \mathrm{n}-3$, present in the corn oil, increases the lifespan of progesterone and estradiol (Piccinato et al. 2010).

We conclude that inclusion of corn oil (3 or $6 \%$ of the diet) enhances blood serum concentrations of estradiol, progesterone, and cholesterol, meanwhile insulin concentration in serum was incremented with $6 \%$ of Corn oil in the diet, however, DWG may be compromised by corn oil added. This change promoted by corn oil in the diet over cholesterol, progesterone, estradiol and even insulin (at $6 \%$ oil inclusion level) could positively influence the reproductive traits in hair sheep in the tropics.

\section{LITERATURE CITED}

AFRC (1993) Technical committee on response to nutrients. Energy and Protein requeriments of rumiants, CBA international, Wallingford, UK. 159p.

Al-Arif AA, Tri SL, Soelih EAT, Lamid M, Scheerlinck JPY (2016) Effects of complete feed based on soy straw on daily weight gain, nutrient consumption, feed efficiency and VFA production of Brahman croass beef cattle. Journal of Applied Environmental and Biological Sciences 6: 155-159

Dupont J, Scaramuzzi R, Reverchon M (2015) The effect of nutrition and metabolic status on the development of follicles, oocytes and embryos in ruminants. Animal 8: 1031-1044

Espinoza JL, Palacios A, Ortega R, Guillen A (2008) Effect of fat supplementation on serum concentrations of progesterone, insulin, growth hormone and some lipid metabolites in Pelibuey ewes. Archivos de Medicina Veterinaria 40: 135-140

Fiorentini G, Carvalho IPC, Messana JD, Canesin RC, Castagnino PS, et al. (2015) Effect of lipid sources with different fatty acid profiles on intake, nutrient digestion and ruminal fermentation of feedlot nellore steers. Asian Australas. Journal of animal science 28: 1583-1591

Fontana R, Torre DS (2016) The deep correlation between energy metabolism and reproduction: A view on the effects of nutrition for women fertility. Nutrients. 8: 2-34

Ghoreishi SM, Zamiri MJ, Rowghani E, Hejazi H (2007) Effect of a calcium soap of fatty acids on reproductive characteristics and lactation performance of fat-tailed sheep. Pakistan Journal of Biological Sciences 10: $2389-2395$.

Gulliver CE, Friend MA, King BJ, Clayton EH (2012) The role of omega-3 polyunsaturated fatty acids in reproduction of sheep and cattle. Animal Reproduction Science 131: 9-22.

Herrera CJ, Quintal FJ, Ku VJ, Williams GL (2003) Effect of polyunsaturated fatty acids on follicular dynamics, pregnancy rate and ovaric response of Pelibuey sheep. Tropical and Subtropical Agroecosystems 2: 101-104

Hess BW, Moss GE, Rule DC (2008) A decade of developments in the area of fat supplementation research with beef cattle and sheep. Journal of Animal Science 86: 188- 204. 
Jenkins TC, Adams CS (2002) The biohydrogenation of linoleamide in vitro and its effects on linoleic acid concentration in duodenal contents of sheep. Journal of Animal Science 80: 533-540.

Lemley CO, Butler ST, Butler WR, Wilson ME (2008) Short communication: Insulin alters hepatic progesterone catabolic enzymes cytochrome P450 2C and 3A in dairy cows. Journal of Dairy Science 91: 641-645.

Lopes N, Scarpa AB, Cappellozza BI, Cooke RF, Vasconcelos JLM (2009) Effects of rumen-protected polyunsaturated fatty acid supplementation on reproductive performance of Bos indicus beef cows. Journal of Animal Science 87: 3935-3943.

Mondal M, Rajkhowa C, Prakash BS (2006) Relationship of plasma estradiol-7beta, total estrogen, and progesterone to estrus behavior in mithun (Bos frontalis) cows. Hormones and Behavior 49: 626-633

Moriel P, Cappellozza BL, Ferraretto L F, Cossolino A A, Rodrigues VFV, et al. (2014) Effects of supplementation of calcium salts of polyunsaturated fatty acids on serum concentrations of progesterone and insulin of pregnant dairy cows. Revista Brasileira de Zootecnia 43: 20-26.

Moriel P, Scatena TS, Filho OG, Cooke RF, Vasconcelos JLM (2008) Concentrations of progesterone and insulin in serum of nonlactating dairy cows in response to carbohydrate source and processing. Journal of Dairy Science 91: 4616- 4621.

Patterson E, Wall R, Fitzgerald GF, Ross RP, Stanton C (2012) Health implications of high dietary omega-6 polyunsaturated fatty acids. Journal of Nutrition and Metabolism 5: 1-16

Perry GA, Swanson OL, Larimore EL, Perry BL, Djira GD, et al. (2014) Relationship of follicle size and concentrations of estradiol among cows exhibiting or not exhibiting estrus during a fixed-time Al Domestic Animal Endocrinology 48: 15-20.

Piccinato CA, Sartori R, Sangsritavong S, Souza AH, Grummer RR, Luchini D, et al. (2010) In vitro and in vivo analysis of fatty acid effects on metabolism of $17 \beta$-estradiol and progesterone in dairy cows. Journal of Dairy Science 93: 1934-1943.

Rahbar B, Safdar AHA, Kor NM (2014) Mechanisms through which fat supplementation could enhance reproduction in farm animal. European Journal of Experimental Biology 24: 340-348.

Robinson RS, Pushpakumara PGA, Cheng Z, Peters AR, Abayasekara DRE, Wathes DC (2002) Effects of dietary polyunsaturated fatty acids on ovarian and uterine function in lactating dairy cows. Reproduction 124: 119-131.

Roy A, Mandal GP, Patra AK (2017) Effects of different vegetable oils on rumen fermentation and conjugated linoleic acid concentration in vitro. Veterinary World 10: 11-16.

Russel AJF, Doney JM, Gunn RG (1969) Subjective assessment of fat in live sheep. Journal of Agricultural Science 72: $451-454$

Salas RG, Herrera CJ, Gutierrez VEE, Ku VJC, Ake LJR (2011) Postpartum ovarian activity resumption and plasma concentration of lipid metabolites and progesterone in cows supplemented with bypass fat. Tropical and Subtropical Agroecosystems 14: 385-392.

Santos JEP, Bilby TR, Thatcher WW, Staples CR, Silvestre FT (2008) Long chain fatty acids of diet as factors influencing reproduction in cattle. Reproduction in Domestic Animals 43: 23-30.

Scaramuzzi RJ, Campbell BK, Downing JA, Kendall NR, Khalid M, et al. (2006) A review of the effects of supplementary nutrition in the ewe on the concentrations of reproductive and metabolic hormones and 
the mechanisms that regulate folliculogenesis and ovulation rate. Reproduction Nutrition Development 46: 339-354.

Staples CR, Burke JM, Thatcher WW (1998) Influence of supplemental fats on reproductive tissues and performance of lactating cows. Journal of Dairy Science 81: 856- 871.

Velazquez MA, Spicer LJ, Wathes DC (2008) The role of endocrine insulinlike growth factor-I (IGF-I) in female bovine reproduction. Domestic Animal Endocrinology 35: 325-342

Vinoles C, Forsberg M, Martin GB, Cajarville C, Repetto J, et al. (2005) Short-term nutritional supplementation of ewes in low body condition affects follicle development due to an increase in glucose and metabolic hormones. Reproduction 129: 299-309.

Wehrman ME, Welsh Jr T H, Williams GL (1991) Diet induced hyperlipidemia in cattle modifies the intrafollicular cholesterol environment, modulates ovarian follicular dynamics, and hastens the onset of postpartum luteal activity. Biology of Reproduction 45: 514-522.

Williams GL (1989) Modulation of luteal activity in postpartum beef cows through changes in dietary lipid. Journal of Animal Science 67: 785-793.

Williams GL, Stanko ER (2000) Dietary fats as reproductive nutraceuticals beef cattle. Proceedings of the American Society of Animal Science. Journal of Animal Science 77: 1-12.

Zachut M, Arieli A, Lehrer H, Argov N, Moallem U (2008) Dietary unsaturated fatty acids influence preovulatory follicle characteristics in dairy cows. Reproduction 135: 683-692.

Zachut M, Arieli A, Moallem U (2011) Incorporation of dietary n-3 fatty acids into ovarian compartments in dairy cows and the effects on hormonal and behavioral patterns around estrus. Reproduction 141: 833-840.

Zhangrui C, Abayasekara DRE, Claire DW (2005) The effect of supplementation with n- 6 polyunsaturated fatty acids on 1-, 2- and 3-series prostaglandin $\mathrm{F}$ production by ovine uterine epithelial cells. Biochimica et biophysica acta 1736: $128-35$ 
